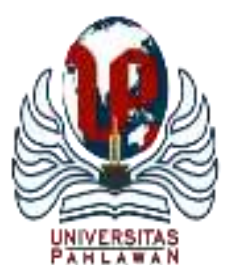

Edukatif : Jurnal Ilmu Pendidikan Volume 3 Nomor 5 Tahun 2021 Halm 3287 - 3295

EDUKATIF: JURNAL ILMU PENDIDIKAN

Research \& Learning in Education

https://edukatif.org/index.php/edukatif/index

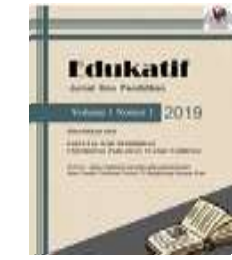

\title{
Presuposisi dan Implikatur pada Negosiasi di Pasar Telagasari serta Implementasinya pada Teks Negosiasi sebagai Bahan Ajar
}

\author{
Atik Sumiyati $^{1 凶}$, Oding Supriadi ${ }^{2}$, Dian Hartati $^{3}$ \\ Universitas Singaperbangsa Karawang, Indonesia ${ }^{1,2,3}$ \\ E-mail : 1710631080035@ student.unsika.ac.id ${ }^{1}$, oding.supriadi@ fkip.unsika.ac.id² ${ }^{2}$, \\ dian.hartati@fkip.unsika.ac.id ${ }^{3}$
}

\begin{abstract}
Abstrak
Sebagai makhluk sosial tidak lepas dari kegiatan berkomunikasi. Tujuan penelitian ini adalah untuk mengetahui bagaimana presuposisi dan implikatur tuturan pada negosiasi masyarakat di pasar Telagasari serta dimanfaatkan sebagai bahan ajar di Sekolah Menengah Atas. Pendekatan penelitian dengan deskriptif kualitatif. Pengumpulan data dengan observasi, wawancara, teknik rekam dan teknik simak bebas libat cakap dan teknik catat serta analisis data dengan metode Miles dan Huberman. Hasil penelitian ini adalah (1) Presuposisi tuturan pada negosiasi di pasar Telagasari yaitu presuposisi potensial memberitahukan keberadaan seseorang, presuposisi faktif menginformasikan suatu peristiwa, presuposisi structural petutur yang tidak dinyatakan dapat dipahami, presuposisi leksikal menunjukkan kalimat-kalimat yang mengacu pada unsure tertentu yang mengikuti kata kerja dan tanda Tanya. Presuposisi Non-faktif dan Presuposisi Konterfaktual tidak terdapat pada negoisasai di pasar Telagasari, (2) Implikatur tuturan yang terdapat pada negosiasi di Pasar Telagasari adalah implikatur konvensional bersifat umum sehingga mudah memahami. Implikatur Percakapan memberikan makna yang temporer, (3) Pemanfaatan hasil analisis presuposisi dan implikatur sebagai bahan ajar materi teks berupa handout berdasarkan Kompetensi Inti dan Kompetensi Dasar dalam silabus 2013. Kesimpulannya terdapat presuposisi dan implikatur tuturan pada negosiasi masyarakat di pasar Telagasari dapat menjadi bahan ajar teks bagi SMA.
\end{abstract}

Kata Kunci: presuposisi, implikatur, negoisasi, bahan ajar.

\section{Abstract}

As social beings, we cannot be separated from communication activities. The purpose of this study was to determine how presuppositions and speech implicatures in community negotiations in the Telagasari market and used as teaching materials in high school. The research approach is descriptive qualitative. Collecting data by observation, interviews, recording techniques and free listening techniques involving conversation and note-taking techniques and data analysis using the Miles and Huberman method. The results of this study are (1) presuppositions of speech in negotiations in the Telagasari market, namely potential presuppositions to inform someone's presence, factive presuppositions to inform an event, structural presuppositions of speeches that are not stated to be understandable, lexical presuppositions show sentences that refer to certain elements that follow the word work and question marks. Non-factive presuppositions and counterfactual presuppositions are not found in the negotiations in the Telagasari market, (2) The speech implicatures found in the negotiations in the Telagasari Market are conventional implicatures of a general nature so that they are easy to understand. Conversational implicatures provide temporary meaning, (3) Utilization of the results of presuppositional and implicature analysis as teaching materials for text materials in the form of handouts based on Core Competencies and Basic Competencies in the 2013 syllabus. for high school.

Keywords: presupposition, implicature, negotiation, teaching materials

Copyright (c) 2021 Atik Sumiyati, Oding Supriadi, Dian Hartati

$\checkmark$ Corresponding author

Email : 1710631080035@student.unsika.ac.id

DOI : https://doi.org/10.31004/edukatif.v3i5.1287

ISSN 2656-8063 (Media Cetak)

ISSN 2656-8071 (Media Online) 
3288 Presuposisi dan Implikatur pada Negosiasi di Pasar Telagasari serta Implementasinya pada Teks Negosiasi sebagai Bahan Ajar - Atik Sumiyati, Oding Supriadi, Dian Hartati

DOI: https://doi.org/10.31004/edukatif.v3i5.1287

\section{PENDAHULUAN}

Sebagai makhluk sosial tidak lepas dari kegiatan berkomunikasi baik menyampaikan dan menerima pesan dari dan kepada orang lain. Dalam tindak komunikasi sering dijumpai salah persepsisaat menanggapi lawan bicara. Hal tersebut terjadi karena kurang memperhatikan kondisi pengetahuan lawan bicara ataulawan bicara tidak memahami makna ucapan penutur yang disampaikan seperlunya.

Pragmatik merupakan bagian ilmu bahasa yang menyoroti tentang makna language in use 'bahasa dalam penggunaannya' yang terikat oleh konteks (Wibowo, 2018). Presuposisi dan implikatur merupakan bagian dari pragmatik yang mengkaji tuturan berdasarkan konteks. Presuposisi atau biasa disebut dengan praanggapan merupakan modal awal dalam setiap pembicaraan. Implikatur secara konseptual bersifat tersirat, artinya maksud sebuah tuturan itu tersembunyi. (Putrayasa, 2014) menjelaskan bahwa implikatur percakapan merupakan salah satu ide yang sangat penting dalam pragmatic. Implikatur percakapan pada dasarnya merupakan suatu teori tentang bagaimana orang menggunakan bahasa, keterkaitan makna suatu tuturan yang tidak terungkapkan secara literal pada tutura itu.

Bahasa adalah sumber daya bagi kehidupan bermasyarakat (Efendi, 2015). Seperti yang kita ketahui komunikasi adalah hal yang paling erat hubungannya degan kegiatan yang dilakukan oleh masyarakat untuk berinteraksi. Misalnya, komunikasi yang terjadi antara penjual dan pembeli di pasar. Pasar merupakan tempat penjual dan pembeli bertemu, barang dan jasa tersedia untuk dijual dan akan terjadi pemindahan hak milik Swastha (dalam (Hestiyana, 2016)). Tawar menawar antara pembeli dengan penjual yang melakukan negosiasi untuk mencapai kesepakatanmelibatkan penggunaan bahasa di dalamnya.

Di dalam berkomunikasi, penutur dan mitra tutur harus memiliki kesamaan latar belakang pengetahuan tentang sesuatu yang dipertuturkan. Hal ini seperti yang dikemukakan (Pranowo, 2012) bahwa komunikasi akan berhasil apabila didukung oleh beberapa faktor, seperti : (1) ada kesepahaman topik yang dibicarakan antara penutur dengan mitra tutur; (2) ada kesepemahaman bahasa yang digunakan oleh penutur kepada mitra tutur; (3) mitra tutur tertarik dengan pesan yang disampaikan oleh penutur; (4) penutur dan mitra tutur samasama dalam konteks dan situasi yang sama; (5) pranggapan penutur terhadap mitra tutur benar; dan (6) penutur mahir memanfaatkan daya bahasa yang menjadikan komunikasi lebih efektif.

Peneliti tertarik meneliti di pasar Telagasari karena pasar Telagasari alternatif tempat belanja terdekat masyarakat wilayah sekitar pasar Telagasari diantaranya pengunjung dari daerah Pasar Talaga, Kalibuaya, Pasir Kamuning, Cariu, Cicadas, Ranggon, Majalaya, Rawamerta, dan masih banyak wilayah jangkauan lainnya. Pengunjung pasar dari berbagai wilayah tersebut tentu memiliki ragam bahasa dan logat yang digunakan berbeda-beda.

Adapun bahasa yang digunakan di pasar Telagasari yaitu lebih banyak pengguna bahasa sunda karena bahasa sunda merupakan bahasa daerah di Telagasari dan sekitarnya, Selain bahasa sunda yang digunakan dalam berinteraksi di pasar Telagasari tak jarang juga beberapa penjual dan pembeli dalam tuturannya menggunakan bahasa Indonesia. Namun lebih dominan pengguna bahasa sunda karena kebanyakan penjual di pasar Telagasari pun merupakan asli dari daerah Telagasari itu sendiri dan hanya beberapa saja penjual yang berasal dari luar daerah Telagasari. Pasar Telagasari tidak pernah sepi pengunjung dari pagi sampai pagi. Karena setelah pasar tutup jam empat dilanjut penjual makanan dan jajanan di pinggir jalan yang terdapat diluar pasar dengan berjejer sepanjang jalan pasar. Oleh sebab itu pasar Telagasari berpotensi menghasilkan tuturan-tuturan berupa presuposisi dan implikatur. Karena negosiasi yang terjadi disampaikan secara implisit maupun eksplisit mengharuskan penutur dengan mitra tutur memahami tuturan yang disampaikan berdasarkan konteks yang terjadi.

Negosiasi merupakan salah satu materi yang diajarkan di Sekolah Menengah Atas (SMA) kelas X semester genap terdapat pada kurikulum yang ditetapkan yaitu kurikulum 2013 tercantum dalam Kompetensi Dasar 3.11 menganalisis isi, struktur (orientasi, pengajuan, penawaran, persetujuan, penutup) dan kebahasaan 
3289 Presuposisi dan Implikatur pada Negosiasi di Pasar Telagasari serta Implementasinya pada Teks Negosiasi sebagai Bahan Ajar - Atik Sumiyati, Oding Supriadi, Dian Hartati

DOI: https://doi.org/10.31004/edukatif.v3i5.1287

teks negosiasi dan Kompetensi Dasar 4.11 Mengkonstruksikan teks negosiasi dengan memrhatikan isi, struktur (orientasi pengajuan, penawaran, persetujuan, penutup dan kebahsaan)(Kebudayaan, 2013). Berdasarkan hasil observasi dengan mewawancarai guru salah satu Sekolah Menengah Atas berlokasi di Rawamerta, bahwa dalam penerapan materi negosiasi di buku paket digunakan contoh negosiasi jual beli mobil. Contoh tersebut dalam kehidupan sehari-hari jauh dari kehidupan siswa. Maka peneliti ingin memberikan contoh negosiasi yang dapat siswa jumpai dalam kehidupan sehari-hari, seperti di pasar.

Penelitian yang terkait dengan implikatur sejauh ini belum banyak dilakukan. Di antaranya Implikatur pada Ujaran Pengguna Jasa Angkutan Umum di Kalimantan Selatan oleh (Hidayatullah, 2009), Pelanggaran Implikatur Percakapan dalam Humor (Tinjauan Pragmatik terhadap Humor Berbahasa Minang di Facebook) oleh (Zawarnis, 2013), Implikatur Percakapan dalam Transaksi Jual Beli di Pasar Tradisional di Kota Palu oleh (Nurmiah, 2014). (Mansyur, 2019) melakukan penelitian dengan judul "Implikatur dan Praanggapan pada Program Debat Terbuka Pasangan Pemimpin Jawa Barat Periode 2018-2023 dengan Tajuk "Debat Publik" (Suatu Kajian Pragmatik), (Nada, 2018) melakukan penelitian dengan judul "Kajian Pragmatik Talk Show Mata Najwa "Cerita Dua Sahabat" Presuposisi, Implikatur, dan Pragmatik". (Fatmawati, 2020) dengan judul "Implikatur Percakapan dalam Transaksi Jual Beli di Pasar Besar Kota Malang (Kajian Pragmatik).

Tujuan dilakukannya penelitian ini adalah untuk mengetahui bagaimana presuposisi tuturan pada negosiasi masyarakat di pasar Telagasari, bagaimana Implikatur tuturan pada negosiasi masyarakat di pasar Telagasari, bagaimana presuposisi dan implikatur tuturan pada negosiasi masyarakat di pasar Telagasari dimanfaatkan sebagai bahan ajar di Sekolah Menengah Atas kelas X.

Berdasarkan tujuan diatas terdapat tiga manfaat yang diharapkan dalam penelitian ini yaitu Memberikan pengetahuan bahasa mengenai wujud presuposisi yang terdapat dalam tuturan masyarakat di pasar Telagasari. Memberikan pengetahuan bahasa mengenai wujud implikatur masyarakat di pasar Telagasari. Hasil analisis dimanfaatkan sebagai bahan ajar teks negoisasi di Sekolah Menengah Atas kelas X.

\section{METODE PENELITIAN}

Pendekatan penelitian dengan pendekatan kualitatif merpuakan tampilan yang berupa kata-kata lisan, atau tertulis yang dicermati oleh peneliti dan benda-benda yang diamati sampai detailnya agar dapat ditangkap makna yang tersirat dalam dokumen atau bendanya (Moleong, 2011)dan metode deskriptif. Objek dalam penelitian ini adalah wujud presuposisi dan implikatur tuturan yang dihasilkan dari tuturan negosiasi masyarakat di pasar Telagasari. Subjek dalam penelitian ini adalah masyarakat di pasar Telagasari. Dalam pengambilan data dilakukan selama dua pekan dari 12 Mei 2021 sampai 24 Mei 2021. Teknik pengumpulan data dengan observasi merupakan meliputi kegiatan pemuatan perhatian suatu objek dengan menggunakan seluruh alat indra (Arikunto, 2010), wawancara, teknik rekam dan teknik simak bebas libat cakap dan teknik catat (Mahsun, 2013). Sumber informan dalam penelitian ini adalah pedagang dan pembeli di Pasar Tegalasari.

Analisis data dengan menggunakan metode Miles dan Huberman (dalam (Sugiyono, 2018)) yang terdiri dari data reduction dimana mereduksi data berarti merangkum, memilih hal-hal yang pokok, memfokuskan pada hal-hal yang penting, dicari tema dan polanya, data display dimana untuk menyajikan data dalam penelitian kualitatif adalah dengan teks yang bersifat naratif, dan conclusion drawing/verification merupakan temuan baru yang sebelumnya belum pernah ada.

Adapun pedoman instrumen penelitian analisis jenis presuposisi menurut (Yule, 2009) terdiri dari presuposisi potensial merupakan suatu tuturan presuposisi yang memberitahukan suatu keberadaan seseorang secara jelas susuai dengan yang terjadi, presuposisi faktif menginformasikan suatu peristiwa atau kegiatan mengikuti kata kerja yang dianggap suatu kejadian nyata sedang dilakukan. presuposisi leksikal dimana sebagai bentuk suatu makna yang dinyatakan formal di asumsikan suatu petutur yang tidak dinyatakan dapat 
3290 Presuposisi dan Implikatur pada Negosiasi di Pasar Telagasari serta Implementasinya pada Teks Negosiasi sebagai Bahan Ajar - Atik Sumiyati, Oding Supriadi, Dian Hartati

DOI: https://doi.org/10.31004/edukatif.v3i5.1287

dipahami. presuposisi struktural merupakan kalimat-kalimat yang mengacu pada unsur ataupun bentuk tertentu yang dianalisis secara utuh dan formal yang mengikuti juga kata kerja dan tanda tanya. presuposisi non-faktif merupakan suatu kebalikan dari faktif yang menyatakan kejadian yang diasumsikan sedang tidak terjadi atau sama sekali benar. presuposisi konterfaktual dimana tidak benar sedang terjadi melainkan merupakan suatu kebalikan yang merupakan suatu khayalan atau angan-angan yang bertolak belakang dengan kenyataan.

Adapun pedoman instrumen penelitian analisis jenis implikatur menurut (Mulyana, 2009) terdiri dari implikatur konvensional dimana Bersifat nontemporer. Pengertiannya bersifat umum, semua orang umumnya sudah mengetahui tentang maksud atau pengertian sesuatu hal tertentu. Tidak memerlukan konteks dalam penggunaannya. implikatur percakapan dihasilkan dari suatu konteks pembicaraan tertentu, memiliki makna yang temporer, konteks sangat berpengaruh dalam peristiwa komunikasi.

\section{HASIL DAN PEMBAHASAN PENELITIAN}

Teknik analisis data yang digunakan dalam penelitian ini menggunakan metode padan. Metode padan merupakan metode yang dipakai untuk menentukan identitas satuan lingual tertentu dengan menggunkan alat penentu diluar bahasa yang bersangkutan (Zaim, 2014) metode padan yang digunakan yaitu metode pragmatis. Negosiasi merupakan proses penetapan keputusan secara bersama antara beberapa pihak yang memiliki keinginan berbeda (Kosasih, 2016).

Presuposisi tuturan pada negosiasi masyarakat di pasar Telagasari terdiri dari tiga yaitu Presuposisi Potensial, faktif, struktural dan leksikal. Terdapat beberapa transaksi antara penjual dan pembeli yang menunjukkan presuposisi potensial. Contohnya seperti yang disampaikan oleh pembeli seperti kalimat "Pak coba mau liat; Kembang goyang berapa jang?" hal ini menunjukkan tuturan yang diucapkan oleh pembeli yang memuat presuposisi potensial yaitu memuat frasa nomina dimana pembeli menyebutkan keberadaan yang disebutkan. Selain pembeli penjual juga menunjukkan kalimat presuposisi potensial contohnya seperti kalimat "Waduh jaman sekarang udah ga ada sendal dua lima buk; boleh neng, masuk dulu; Boleh teh kerudungnya", hal ini menunjukkan tuturan yang diucapkan oleh penjual yang memuat presuposisi potensial yaitu memuat frasa nomina dimana penjual menyebutkan keberadaan yang disebutkan. Terdapat beberapa transaksi antara penjual dan pembeli yang menunjukkan presuposisi faktif. Contohnya seperti yang disampaikan oleh penjual seperti kalimat "Boleh teh kerudungnya; Ada banyak, nih warna lain juga banyak; Lima ribu lagi lah sok, apa lagi teh, kerudungnya sekalian; Ada bu di dalem, masuk dulu. Banyak neng nihmodelnya mau yang mana?".Terdapat beberapa transaksi antara penjual dan pembeli yang menunjukkan kalimat presuposisi structural. Contohnya seperti yang disampaikan oleh pembeli seperti kalimat " Berapa duit ini?" tuturan yang diucapkan oleh pembeli terdapat jenis presuposisi structural. Presuposisi structural juga diucapkan oleh penjual seperti kalimat "Cari apa neng; Banyak neng nihmodelnya mau yang mana?". Terdapat beberapa transaksi antara penjual dan pembeli yang menunjukkan kalimat presuposisi leksikal contohnya seperti kalimat yang disampaikan oleh pembeli sepert "Mahal-mahal amat sendal anak kecil doang kirain dua limaan; Pasnya berapa?; Kirain delapan puluh; Ga bisa kurang; Lempengin ke buk dua ratus udah; Kerupuk juga sekarang pada mahal ya; Masa sama kaya daging; Rok plisketnya mau yang item; Kirain dapet enam puluh; kemaren temen saya beli enam puluh; Tujuh puluh aja lima ribunya buat beli es; Melinjo sih?; Seladanya aja lima ribu; Biasanya empat ribu; yang ini empat lima kali; kirain kaya gini dapet 80; ko adaan ya; Tiga lima kali sisa bubuknya juga ini", tuturan yang diucapkan oleh pembeli kepada penjual tersebut terdapat presuposisi leksikal. Presuposisi leksikal juga disamapaikan pada penjual seperti kalimat "Waduh jaman sekarang udah ga ada sendal dua lima buk; Belum dapet bu; Udah harga pas buk; boleh neng, masuk dulu; Iya buk dimana-mana juga sama; Sok cari dimana ada kaya gini enam puluh; paling seratus sih neng boleh; Sok lah kasian takut aus. Apa lagi nih?; Jauh teh, paling sebelas; Lima ribu lagi lah sok, apa lagi teh, 
3291 Presuposisi dan Implikatur pada Negosiasi di Pasar Telagasari serta Implementasinya pada Teks Negosiasi sebagai Bahan Ajar - Atik Sumiyati, Oding Supriadi, Dian Hartati

DOI: https://doi.org/10.31004/edukatif.v3i5.1287

kerudungnya sekalian; Empat lima sok lah biar langganan".

Implikatur Tuturan Pada Negosiasi Masyarakat di pasar Telagasari terdiri dari implikatur konvensional dan implikatur percakapan. Terdapat beberapa transaksi antara penjual dan pembeli yang menunjukkan kalimat implikatur konvensional seperti yang disampaikan oleh pembeli contohnya "Mahal-mahal amat sendal anak kecil doang. Kirain dua limaan; Maunya tiga lima; Kirain delapan puluh; seratus kali; Masa sama kaya daging; Mentang-mentang mau lebaran mahal banget". Terdapat pula kalimat implikatur konvensional seperti yang disampaikan oleh pembeli contohnya "Waduh zaman sekarang udah ga ada sendal dua lima bu; Boleh neng kopiahnya; Penglaris lah muda-mudahan awet barangnya buat si neng". Terdapat beberapa transaksi antara penjual dan pembeli yang menunjukkan kalimat implikatur percakapan contohnya "Pembeli: ah gamau kemahalan; Penjual: lima puluh sok (sembari membungkus sandalnya) nih bawa, Penjual: Sembilan lima udah kalo mau; Pembeli: kembali lima ribu (membayar).

Pemanfaatan hasil analisis presuposisi dan implikatur pada negosiasi masyarakat di pasar Telagasari sebagai bahan ajar materi teks negosiasi. Hasil analisis presuposisi dan implikatur pada negosiasi masyarakat di pasar Telagasari dapat dimanfaatkan sebagai bahan ajar pada pembelajaran Teks Negosiasi di Sekolah Menengah Atas (SMA) kelas X yaitu bahan ajar berupa handout sehingga siswa mampu menentukan pengertian teks negosiasi, siswa mampu menentukan ciri-ciri teks negosiasi, siswa mampu menentukan struktur teks negosiasi, siswa mampu menentukan kebahasan teks negosiasi dan siswa mampu menyusun teks negosiasi dan mempraktikannya secara lisan maupun tulisan. Dalam handout teks negosiasi peneliti menyusun berdasarkan hasil analisis presuposisi dan implikatur pada negosiasi masyarakat di pasar. Materi ajar yang disusun oleh peneliti terlebih dahulu dikaji berdasarkan Kompetensi Inti dan Kompetensi Dasar dalam silabus 2013, setelah itu peneliti menentukan dua Kompetensi Dasar (KD) yang akan digunakan berupa Kompetensi Dasar 3.11 menganalisis isi, struktur (orientasi, pengajuan, penawaran, persetujuan, penutup) dan kebahasaan teks negosiasi dan Kompetensi Dasar 4.11 Mengkonstruksikan teks negosiasi dengan memperhatikan isi, struktur (orientasi pengajuan, penawaran, persetujuan, penutup dan kebahsaan). Sementara itu, peneliti menentukan Indikator Pencaaian Kompetensi (IPK) yang hendak dicapai, yaitu 3.11.1 Menentukan struktur: orientasi (pengajuan, penawaran, dan persetujuan), 3.11.3 Menentukan ciri kebahasaan dalam teks negosiasi, 4.11.1 Menyusun teks negosiasi dengan memerhatikan struktur teks negosiasi yang terjadi di pasar Telagasari dan 4.11.2 Menyususun teks negosiasi yang terjadi di pasar telagasari dengan memerhatikan aspek kebahasaan.

Presuposisi tuturan pada negosiasi masyarakat di pasar Telagasari dimana terdapat beberapa transaksi antara penjual dan pembeli yang menunjukkan presuposisi potensial dimana memberitahukan suatu keberadaan seseorang secara jelas susuai dengan yang terjadi. Sebelum bertutur, pembeli atau penjual memiliki presuposisi bahwa penjual atau pembeli mengetahui maksudnya, kata-kata yang digunakan dalam presuposisi potensial seperti penggunakan kata "pak, buk, neng, teh, jang”. Contoh kalimat yang disampaikan pembeli "Kembang goyang berapa jang?" pada konteks tuturan yang terjadi di pasar pada penjual kue kering berupa kembang goyang dimana pembeli menanyakan harga kembang goyang sebanyak satu bungkusnya. Frasa nomina yang disebutkan pada kata "jang" merupakan bentuk pronominal sapaan langsung pembeli kepada penjual seorang laki-laki yang pantas dipanggil jang oleh pembeli karena penjual masih muda dan penjual lebih muda dari pembeli. Contoh kalimat yang disampaikan penjual "Waduh jaman sekarang udah ga ada sendal dua lima buk". Sebelum bertutur, PN memiliki presuposisi bahwa PM mengetahui maksudnya, yaitu pada konteks tuturan yang terjadi di pasar pada penjual sandal dimana penjual jaman sekarang harga sandal sudah naik dan mahal. frasa nomina yang disebutkan pada kata "buk" merupakan bentuk pronomina sapaan langsung penjual kepada pembeli seorang perempuan yang pantas dipanggil ibu karena terlihat pada usia ibu-ibu.

Terdapat beberapa transaksi antara penjual dan pembeli yang menunjukkan presuposisi faktif dimana menginformasikan suatu peristiwa atau kegiatan mengikuti kata kerja yang dianggap suatu kejadian nyata 
3292 Presuposisi dan Implikatur pada Negosiasi di Pasar Telagasari serta Implementasinya pada Teks Negosiasi sebagai Bahan Ajar - Atik Sumiyati, Oding Supriadi, Dian Hartati

DOI: https://doi.org/10.31004/edukatif.v3i5.1287

sedang dilakukan, contohnya pada kalimat yang disampaikan penjual "Ada bu di dalem, masuk dulu. Banyak neng nihmodelnya mau yang mana?". Konteks tuturan terjadi di pasar pada penjual celana terdapat presuposisi faktif dapat dilihat berdasarkan tuturan "Banyak neng nihmodelnya mau yang mana?". Hal tersebut mempresuposisikan bahwa penjual kerudung memberitahukan kepada pembeli bahwa di tokonya menjual celana dengan berbagai macam model sehingga menimbulkan presuposisi faktif karena pada kata tersebut hasil presuposisi yang terjadi sudah benar adanya. Contoh kalimat yang disampaikan pembeli "Ada banyak, nih warna lain juga banyak". Konteks tuturan yang terjadi yaitu di pasar pada penjual rok dimana terdapat tuturan berupa presuposisi dilihat dari tuturan "Ada banyak, nih warna lain juga banyak" hal tersebut mempresuposisikan bahwa penjual rok memberitahukan kepada pembeli bahwa di tokonya tersebut menjual banyak rok dengan berbagai warna. Pada tuturan tersebut kata yang menjelaskan memberitahukan dan menjual dapat dikatakan menghasilkan jenis presuposisi faktif karena pada kata tersebut hasil presuposisi yang terjadi sudah benar adanya.

Terdapat beberapa transaksi antara penjual dan pembeli yang menunjukkan presuposisi struktural dimana dimana sebagai bentuk suatu makna yang dinyatakan formal di asumsikan suatu petutur yang tidak dinyatakan dapat dipahami, contohnya pada kalimat yang disampaikan penjual "Banyak neng nihmodelnya mau yang mana?", Konteks yang terjadi di pasar pada penjual celana dimana penjual bertanya "mau yang mana" mempresuposisikan pada kata "banyak" merupakan suatu informasi yang disampaikan bahwa toko tersebut menjual berbagai macam model celana kepada pembeli seorang perempuan dengan membawa anak perempuan yang mencari celana untuk anaknya tersebut. Kata tanya mana merupakan kata tanya untuk menanyakan salah seorang atau salah satu benda atau hal dari suatukelompok (kumpulan). Contoh kalimat yang disampaikan pembeli "Berapa duit ini?". Konteks tuturan yang terjadi yaitu di pasar pada penjual sandal dimana pembeli seorang ibu yang membawa anak perempuannya mempertanyakan harga sandal yang disukai anaknya kepada penjual. Pada tuturan tersebut terdapat jenis presuposisi struktural, yaitu digunakannya kata tanya "berapa" yang mempresuposisikan pada kata "ini" menunjukkan barang berupa sandal yang dipertanyakan harganya. Kata tanya berapa merupakan kata tanya untuk menanyakan bilangan yang mewakili jumlah, ukuran, nilai, harga, satuan, waktu.

Terdapat beberapa transaksi antara penjual dan pembeli yang menunjukkan presuposisi leksikal merupakan kalimat-kalimat yang mengacu pada unsur ataupun bentuk tertentu yang dianalisis secara utuh dan formal yang mengikuti juga kata kerja dan tanda tanya, contohnya pada kalimat yang disampaikan pembeli "Mahal-mahal amat sendal anak kecil doang kirain dua limaan". Konteks tuturan terjadi di pasar pada penjual sandal dimana pembeli protes dengan harga sandal anak kecil yang harganya sangat mahal. Pada tuturan tersebut terdapat presuposisi leksikal. Dapat dilihat pada tuturan "Mahal-mahal amat sendal anak kecil doang" yang menimbulkan presuposisi bahwa biasanya sandal anak kecil tidak semahal harga yang disebutkan oleh penjual dan harga tersebut seharusnya harga yang sesuai untuk sandal orang dewasa. Contoh kalimat yang disampaikan penjual "Belum dapet bu". Konteks tuturan terjadi di pasar pada penjual sandal terdapat presuposisi leksikal terlihat dengan tuturan "Belum dapet bu" dimana penjual memberitahukan kepada pembeli bahwa harga yang ditawar oleh pembeli tidak sesuai dengan barang yang dijual sehingga tidak dapat keuntungan jika menjual dengan harga yang ditawar oleh pembeli.

Pada transaksi antara penjual dan pembeli yang menunjukkan di Pasar Telagasari tidak menggunakan Presuposisi Non-faktif dimana merupakan suatu kebalikan dari faktif yang menyatakan kejadian yang diasumsikan sedang tidak terjadi atau sama sekali benar. Serta tidak menggunakan Presuposisi Konterfaktual dimana tidak benar sedang terjadi melainkan merupakan suatu kebalikan yang merupakan suatu khayalan atau angan-angan yang bertolak belakang dengan kenyataan.

Implikatur Tuturan Pada Negosiasi Masyarakat di Pasar Telagasari dimana Implikatur Konvensional bersifat umum, semua orang umumnya sudah mengetahui tentang maksud atau pengertian sesuatu hal tertentu contohnya pada kalimat yang disampaikan pembeli "Mahal-mahal amat sendal anak kecil doang. Kirain dua 
3293 Presuposisi dan Implikatur pada Negosiasi di Pasar Telagasari serta Implementasinya pada Teks Negosiasi sebagai Bahan Ajar - Atik Sumiyati, Oding Supriadi, Dian Hartati

DOI: https://doi.org/10.31004/edukatif.v3i5.1287

limaan". Konteks tuturan terjadi di pasar pada penjual sandal dimana pembeli adalah seorang ibu yang membawa anak kecil perempuan dan ingin membelikan sandal untuk anaknya dengan harga sandal tujuh puluh lima ribu. Dalam percakapan mengandung implikatur konvensional. Hal tersebut dapat dilihat pada tuturan "Mahal-mahal amat sendal anak kecil doang. Kirain dua limaan" tuturan tersebut mengimplikasikan bahwa biasanya sandal anak kecil lebih murah dari sandal dewasa, harga tujuh puluh lima ribu menurut pembeli lebih sesuai untuk harga sandal orang dewasa dan sangat mahal untuk sandal anak kecil selain itu, pembeli mengira sandal tersebut seharga dua puluh lima ribu dan harga tersebut disebutkan oleh pembeli dengan maksud menawar dan berharap sandal tersebut bisa menjadi dua puluh lima ribu. Contoh kalimat yang disampaikan penjual "Waduh zaman sekarang udah ga ada sendal dua lima bu". Konteks tuturan terjadi di pasar pada penjual sandal dimana pembeli adalah seorang ibu yang membawa anak kecil perempuan dan ingin membelikan sandal untuk anaknya. Dalam percakapan mengandung implikatur konvensional. Hal tersebut dapat dilihat pada tuturan "Waduh jaman sekarang udah ga ada sendal dua lima bu" tuturan tersebut mengimplikasikan bahwa zaman yang semakin modern memberikan perubahan pada semua hal termasuk harga barang berupa sandal menjadi sangat mahal sekali dimana zaman sebelumnya harga sandal anak kecil sangat murah dan perbandingannya dengan zaman sekarang sangat jauh.

Implikatur Percakapan dimana dihasilkan dari suatu konteks pembicaraan tertentu, memiliki makna yang temporer, konteks sangat berpengaruh dalam peristiwa komunikasi, contohnya percakapan pada penjual dan pembeli "Pembeli: pasnya berapa?; Penjual: Enam lima tuh udah harga murah; Pembeli: Jadi berapa?; Penjual: sok lah enam lima kalo mau". Dalam percakapan tersebut merupakan tuturan yang diucapkan oleh penjual kepada pembeli kepada penjual yang memuat implikatur percakapan. Hal tersebut dilihat pada tuturan "Enam lima tuh udah harga murah" berdasarkan konteks yang terjadi di pasar pada penjual sandal dimana menurut penjual pembeli menawar harga sandal sangat murah dimana zaman semakin modern dan segala sesuatu menjadi mahal termasuk sandal sehingga penjual mengatakan bahwa harga enam puluh lima ribu merupakan harga yang murah untuk sandal anak kecil di zaman sekarang.

Pemanfaatan Hasil Analisis Presuposisi dan Implikatur Pada Negosiasi Masyarakat di Pasar Telagasari Sebagai Bahan Ajar Materi Teks Negosiasi dimana pada proses kegiatan negosiasi di pasar sangat memerlukan pemahaman terhadap konteks dan makna tersirat yang disampaikan dari tiap tuturan penjual dan pembeli sehingga proses negosiasi dapat berjalan dengan lancar. Sudah menjadi sebuah kebiasaan penutur di pasar menyampaikan tuturan dengan seperlunya hanya dengan berasumsi terhadap mitra tutur dan konteks tuturan dimana tuturan disampaikan secara tersirat dan sebagai mitra tutur tentu harus berusaha memahami makna tuturan yang disampaikan oleh penutur dengan begitu kegiatan negosiasi menjadi lancar atau prosesnya akan lebih cepat dalam mencapai kesepakatan.

Hasil analisis presuposisi dan implikatur pada negosiasi masyarakat di pasar Telagasari dapat dimanfaatkan sebagai bahan ajar pada pembelajaran Teks Negosiasi di Sekolah Menengah Atas (SMA) kelas $\mathrm{X}$ yaitu bahan ajar berupa handout sehingga siswa mampu menentukan pengertian teks negosiasi, siswa mampu menentukan ciri-ciri teks negosiasi, siswa mampu menentukan struktur teks negosiasi, siswa mampu menentukan kebahasan teks negosiasi dan siswa mampu menyusun teks negosiasi dan mempraktikannya secara lisan maupun tulisan.

Dalam handout teks negosiasi peneliti menyusun berdasarkan hasil analisis presuposisi dan implikatur pada negosiasi masyarakat di pasar. Materi ajar yang disusun oleh peneliti terlebih dahulu dikaji berdasarkan Kompetensi Inti dan Kompetensi Dasar dalam silabus 2013, setelah itu peneliti menentukan dua Kompetensi Dasar (KD) yang akan digunakan berupa Kompetensi Dasar 3.11 menganalisis isi, struktur (orientasi, pengajuan, penawaran, persetujuan, penutup) dan kebahasaan teks negosiasi dan Kompetensi Dasar 4.11 Mengkonstruksikan teks negosiasi dengan memrhatikan isi, struktur (orientasi pengajuan, penawaran, persetujuan, penutup dan kebahsaan). Sementara itu, peneliti menentukan Indikator Pencaaian Kompetensi (IPK) yang hendak dicapai, yaitu 3.11.1 Menentukan struktur: orientasi (pengajuan, penawaran, dan 
3294 Presuposisi dan Implikatur pada Negosiasi di Pasar Telagasari serta Implementasinya pada Teks Negosiasi sebagai Bahan Ajar - Atik Sumiyati, Oding Supriadi, Dian Hartati

DOI: https://doi.org/10.31004/edukatif.v3i5.1287

persetujuan), 3.11.3 Menentukan ciri kebahasaan dalam teks negosiasi, 4.11.1 Menyusun teks negosiasi dengan memerhatikan struktur teks negosiasi yang terjadi di pasar Telagasari dan 4.11.2 Menyususun teks negosiasi yang terjadi di pasar telagasari dengan memerhatikan aspek kebahasaan.

Pada KD 3.11 dan 4.11 terlihat bahwa dalam KD tersebut tentunya ketika siswa sudah diberikan pengertian mengani konsep dasar teks negosiasi berupa struktur dan kebahasaannya. Sebelum siswa dapat mempraktikannya, dalam handout yang telah disusun oleh peneliti membangun konteks yang perlu diperhatikan dalam bernegosiasi agar memahami maksud tuturan yang disampaikan secara tersirat. Dalam praktiknya siswa menyajikan gagasan dan pendapat mengenai contoh teks negosiasi yang telah disediakan secara berkelompok kemudian menyusun teks negosiasi dengan memperhatikan struktur dan kebahasaan teks negosiasi serta memahami makna yang tersirat.

Hasil penelitian ini sesuai dengan penelitian (Mansyur, 2019) dengan judul "Implikatur dan Praanggapan pada Program Debat Terbuka Pasangan Pemimpin Jawa Barat Periode 2018-2023 dengan Tajuk "Debat Publik" (Suatu Kajian Pragmatik)" pada penelitian ini mengkaji jenis implikatur dan praanggapan pada program debat terbuka pasangan pemimpin jawa barat dan ditemukan data berupa implikatur konvensional sebesar 62,162\%, konvensional sebesar 22,98\% dan praanggapan 14,86\%. Kemudian penelitian serupa juga dilakukan oleh (Nada, 2018) dengan judul "Kajian Pragmatik Talk Show Mata Najwa "Cerita Dua Sahabat" Presuposisi, Implikatur, dan Pragmatik" pada penlitian ini mengkaji jenis-jenis presuposisi dan Implikatur pada acara Talk Show Mata Najwa dan berhasil mengungkap jenis-jenis presuposisi berupa presupoisis potensial dan presupoisi faktif kemudian jenis-jenis implikatur berupa implikatur percakapan umum, implikatur berskala, dan implikatur percakapan khusus.

\section{KESIMPULAN}

Berdasarkan analisis dan pembahasan maka dapat disimpulkan Presuposisi tuturan yang terdapat pada negosiasi masyarakat di pasar Telagasari yaitu presuposisi potensial yang menunjukkan memberitahukan keberadaan seseorang, presuposisi faktif dimana menginformasikan suatu peristiwa, presuposisi structural dimana petutur yang tidak dinyatakan dapat dipahami, presuposisi leksikal yang menunjukkan kalimat-kalimat yang mengacu pada unsure tertentu yang mengikuti juga kata kerja dan tanda Tanya. Presuposisi tuturan yang tidak terdapat pada negosiasi masyarakat di pasar Telagasari adalah Presuposisi Non-faktif dan Presuposisi Konterfaktual. Implikatur tuturan yang terdapat pada negosiasi masyarakat di Pasar Telagasari adalah implikatur konvensional dimana bersifat umum sehingga orang mudah memahami. Implikatur Percakapan dimana memberikan makna yang temporer. Pemanfaatan hasil analisis presuposisi dan implikatur pada negosiasi masyarakat di pasar telagasari sebagai bahan ajar materi teks negosiasi di Sekolah Menengah Atas (SMA) kelas X yaitu bahan ajar berupa handout berdasarkan Kompetensi Inti dan Kompetensi Dasar dalam silabus 2013.

\section{UCAPAN TERIMA KASIH}

Penulis mengucapkan terima kasih kepada para dosen pembimbing yang telah membantu menyumbangkan ilmunya guna terselesaikannya penelitian ini. Penulis juga mengucapkan terima kasih kepada keluarga dan teman-teman yang telah mendukung penelitian ini.

\section{DAFTAR PUSTAKA}

Arikunto, S. (2010). Manajemen Penelitian. Rineka Cipta.

Efendi, S. (2015). Tata Bahasa Acauan Bahasa Indonesia. Pustaka Mandiri.

Fatmawati, H. (2020). Implikatur Percakapan Dalam Transaksi Jual Di Pasar Besar Kota Malang (Kajian 
3295 Presuposisi dan Implikatur pada Negosiasi di Pasar Telagasari serta Implementasinya pada Teks Negosiasi sebagai Bahan Ajar - Atik Sumiyati, Oding Supriadi, Dian Hartati

DOI: https://doi.org/10.31004/edukatif.v3i5.1287

Pragmatik). Skripsi Universitas Brawijaya Malang.

Hestiyana. (2016). Implikatur Percakapan Dalam Transaksi Jual Beli Di Pasar Hewan Wage Tulakan. Undas, $12(2), 11--24$

Hidayatullah, D. (2009). Implikatur Pada Ujaran Pengguna Jasa Angkutan Umum Di Kalimantan Selatan. Undas Jurnal Hasil Penelitian Bahasa Dan Sastra, V(1), 74-86.

Kebudayaan, K. P. Dan. (2013). Bahasa Indonesia: Ekspresi Diri Dan Akademik.

Kosasih, E. (2016). Cerdas Berbahasa Indonesia Untuk Sma/Ma Kelas X. Erlangga.

Mahsun. (2013). Metode Penelitian Bahasa: Tahap Strategi, Metode Dan Tekniknya. Raja Grafindo Persada.

Mansyur. (2019). Implikatur Dan Praanggapan Pada Program Debat Terbuka Pasangan Pemimpin Jawa Barat Periode 2018-2023 Dengan Tajuk "Debat Publik Kedua Cagub Jawa Barat" (Suatu Kajian Pragmatik). Diskursus: Jurnal Pendidikan Bahasa Indonesia, 2(1), 49-54.

Moleong, L. J. (2011). Metodologi Penelitian Kualitatif. Pt Remaja Rosdakarya.

Mulyana. (2009). Kajian Wacana: Teori, Metode \& Aplikasi Prinsip-Prinsip Analisis Wacana. Tiara Wacana.

Nada, Q. (2018). Implikatur Dan Praanggapan Pada Program Debat Terbuka Pasangan Pemimpin Jawa Barat Periode 2018-2023 Dengan Tajuk "Debat Publik." In Doctoral Dissertation. Universitas Diponegoro.

Nurmiah. (2014). Implikatur Percakapan Dalam Transaksi Jual Beli Di Pasar Tradisional Di Kota Palu. Multilingual Jurnal Kebahasaan Dan Kesastraan, Xiii(2), 196-207.

Pranowo. (2012). Berbahasa Secara Santun. Pustaka Pelajar.

Putrayasa, I. B. (2014). Pragmatik. Graha Ilmu.

Sugiyono. (2018). Metode Penelitian Kuantitatif, Dan Kualitatif Dan R \& D. Alfabeta.

Wibowo. (2018). Etnopragmatik Bingkai Budaya Jawa Pada Tuturan. Cv. Sarnu Untung.

Yule. (2009). Pragmatik. Pustaka Pelajar.

Zaim, M. (2014). Metode Penelitian Bahasa. Fbs Unp Pres.

Zawarnis, Y. (2013). Pelanggaran Implikatur Percakapan Dalam Humor (Tinjauan Pragmatik Terhadap Humor Berbahasa Minang Di Facebook). Kelasa Jurnal Kelebat Masalah Bahasa Dan Sastra, Viii(1), $49-64$. 